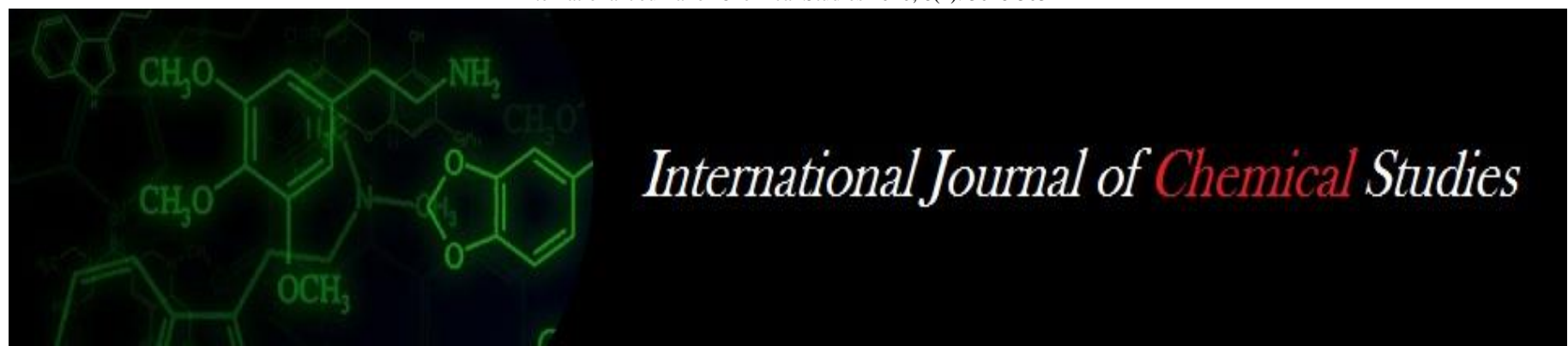

P-ISSN: 2349-8528

E-ISSN: 2321-4902

www.chemijournal.com

IJCS 2020; 8(1): 3028-3034

(C) 2020 IJCS

Received: 24-11-2019

Accepted: 28-12-2019

Amit Pant

M.Sc. Scholar, Department of

Agronomy, G.B.P.U.A. \& T.,

Pantnagar, Uttarakhand, India

\section{PC Pandey}

Professor, Department of Agronomy, G.B.P.U.A. \& T.,

Pantnagar, Uttarakhand, India

Akansha Rawat

M.Sc. Scholar, Department of Agronomy, G.B.P.U.A. \& T.,

Pantnagar, Uttarakhand, India

Garima Kaushik Parashar M.Sc. Scholar, Department of Agronomy, G.B.P.U.A. \& T., Pantnagar, Uttarakhand, India

Corresponding Author:

Amit Pant

M.Sc. Scholar, Department of

Agronomy, G.B.P.U.A. \& T.

Pantnagar, Uttarakhand, India

\section{Impact on soil fertility status and concentration of nutrient $(N, P$ and $K)$ in grain by adopting nutrient management practices in rice crop (Oryza sativa L.) Under different establishment methods}

\author{
Amit Pant, PC Pandey, Akansha Rawat and Garima Kaushik Parashar
}

DOI: https://doi.org/10.22271/chemi.2020.v8.i1at.8733

\begin{abstract}
The present investigation was carried out to find the Impact on soil fertility status by adopting nutrient management practices in Rice Crop (Oryza Sativa L.) under different establishment methods. The experiment was conducted in $\mathrm{A}_{2}$ block at N. E. Borlaug Crop Research Centre, G.B. Pant University of Agriculture and Technology, Pantnagar, District Udham Singh Nagar, Uttarakhand. The treatments consisting three establishment methods in main plots and five nutrient management practices in sub plots (fifteen combination) was laid out in split plot design (SPD) with three replications. The result revealed that, the concentration of nutrient (viz. N, P and K) in grain as well as in straw was affected significantly and was higher with transplanting method. Application of RDF(recommended dose of fertilizer) +5 tFYM/ha exhibited statistically higher concentration and uptake, while RDF $\mathrm{RDF}$ (recommended dose of fertilizer) alone recorded significantly less concentration and uptake value of all nutrients. The status of available $\mathrm{N}, \mathrm{P}$ and $\mathrm{K}$ in soil remained unaffected due to different establishment methods, however higher values were obtained in transplanting method with application of $\mathrm{RDF}+5 \mathrm{tFYM} / \mathrm{ha}$.
\end{abstract}

Keywords: Rice crop (Oryza sativa L.), nutrient management, establishment methods

\section{Introduction}

Rice (Oryza sativa L.) is familiar as a superlative commodity to mankind, because it is actually a life, an ethos, a tradition and a means of livelihood to millions of people. It is also an important staple foodstuff providing 66-70 per cent body calorie intake of the consumers which are about 50 per cent of the world's population residing in Asia, where 90 per cent of the world's rice is full-grown and consumed. In India, it is appraised that the demand, of rice will be of 140 million tonnes in 2025. At present, India has 42.41 million hectare of cultivated land under rice cultivation with a production of 106.04 million tonnes (Economic survey of India, 2014) ${ }^{[12]}$.

Modification in rice establishment methods can be used to shrink cost of cultivation even the productivity remains the same or increased. Transplanting method is the common practice of rice establishment in most of the irrigated areas in the world. Due to resource constraints, especially water and labourers, dry seeding under dry condition is now emerging new trend in rice cultivation. Aerobic method of rice cultivation, where fields remain unsaturated throughout the season like an upland crop offers an opportunity to produce rice with less water and tillage operations and rapid reduction in total water usage from $27-51 \%$ with increased productivity of $32-88 \%$ (Bouman et al., 2002) ${ }^{[8]}$. This practice is an alternative to the conventional rice cultivation system in regions where rainfall and fresh water resources are limited and becoming popular as it reduces the cost of production, by reduced irrigation and realizing good yields and water productivity. Input water savings of 35-57\% can be achieved for dry seeded rice sown into non-puddled fields (Singh et al., 2003) ${ }^{[51]}$. Another method of direct seeding is wet-direct seeding, as it involves puddled condition for sowing pregerminated rice seeds, in well puddle, well levelled and recently drained seed beds. (Tuong and Bouman, 2003) ${ }^{[57]}$. 
Nutrient management is also a major constituent of soil and crop management system in rice. Knowing the required nutrients for all stages of growth and understanding the soil's ability to supply them is critical to profitable crop production. Among major nutrients like NPK, nitrogen is a key nutrient of rice production and requires proper application management (Nedunchezhiyan and Laxminarayan, 2011) ${ }^{[36]}$. In estimation it was found that 24 per cent of the increase in Asian rice was attributed to use of fertilizers, mainly nitrogen (Baker et al., 1985) ${ }^{[5]}$, (Alam et al., 2005) ${ }^{[1]}$.

Also injudicious use of high analysed fertilizers often leads to imbalance in nutrients especially micronutrients, which ultimately cause deterioration of soil physio-chemical properties and steadily decreases crop yield (Gupta et al., 2002) ${ }^{[19]}$. Continuous use of inorganic fertilizers has brought loss of vital soil fauna and flora. This calls for the development of integrated nutrient management systems (INMS) where reduced amount of chemical fertilizer is supplemented through organic sources for improvement and maintenance of soil fertility leading to sustained crop production, as organic manures modify the soil physical behaviour and increases the efficiency of applied nutrients (Pandey et al., 2007) ${ }^{[39]}$.

The use of farmyard manure and compost to improve rice yield is recognized by farmers for many centuries. By recycling of all the organic wastes, China has been able to grow in a sustainable manner for decades with no micronutrient problems and has provided healthy environment to their people (FAO, 1977) ${ }^{[15]}$. In India too, there is tremendous potential of recycling organic waste (Gaur et al., $1990)^{[16]}$.

\section{Materials and Methods}

The experiment was conducted in $\mathrm{A}_{2}$ block at N. E. Borlaug Crop Research Centre, G.B. Pant University of Agriculture and Technology, Pantnagar, District Udham Singh Nagar, Uttarakhand during the kharif season of 2015. This experiment was laid out in spilt-plot design keeping establishment method in main plots and nutrient management practices in sub-plots with three replications. The details of treatments in this study are given below:

Treatments:- (split plot design)

Establishment methods (Main Plot)

T1: Aerobic (Direct seeded rice)

T2: Wet-direct seeding

T3: Transplanting

\section{Nutrient management practices (Sub Plot)}

F1: RDF (Recommended dose of fertilizer) (120:60:40) N: $\mathrm{P}_{2} \mathrm{O}_{5}$ : $\mathrm{K}_{2} \mathrm{O} \mathrm{kg} / \mathrm{ha}$

F2: $75 \%$ RDF (90:45:30) +FYM/ha (Equivalent to $25 \% \mathrm{~N}$ dose)

F3: $150 \%$ RDF (180:90:60)

F4: RDF (90:60:40) (LCC based N application)

F5: RDF (120:60:40) + 5 tonnes FYM/ha (Location specific)

Note: In direct seeding and Wet direct seeding $\mathrm{N}$ was applied as $1 / 4$ basal $+1 / 2$ tillering $+1 / 4$ PI and in Transplanted rice $\mathrm{N}$ was applied as $1 / 2$ basal $+1 / 4$ tillering $+1 / 4 \mathrm{PI}$.

Variety: HKR-47, Replication: 3, Treatments: 15, Total No. of plots: 45

\section{Fertilizer application}

Before seeding, full dose of phosphorus and potassium and $25 \% \mathrm{~N}$ was applied as basal in aerobic, wet-direct seeded plots and $50 \% \mathrm{~N}$ with full dose of phosphorus and potassium was applied as basal in transplanted rice plots through urea $(46 \% \mathrm{~N})$, NPK fertilizer (12:32:16) and Murate of potash $\left(60 \% \mathrm{~K}_{2} \mathrm{O}\right)$, respectively and incorporated into soil, as per dose required in a particular treatment. The remaining quantity of nitrogen was top dressed in two splits: at tillering (50\% in aerobic and wet-direct seeded plots and $25 \%$ in transplanted rice plots) and at panicle initiation stage $25 \% \mathrm{~N}$ was applied in all plots as per the treatment. Also prior to sowing or transplanting FYM was applied as per treatment on required sub-plots and thoroughly incorporated into the top 15 $\mathrm{cm}$ soil with the help of spade manually. In treatment involving application of nitrogen on the basis of leaf colour char (LCC), full recommended dose of phosphorus, potassium and one-fourth of the recommended dose of nitrogen (30 $\mathrm{kg} / \mathrm{ha}$ ) was applied as basal and remaining nitrogen was top dressed at the rate of $30 \mathrm{~kg} \mathrm{~N} / \mathrm{ha}$ two times, when the average of the reading of the leaves of selected rice plants was found less than 4 in leaf colour chart (LCC).

\section{Leaf colour chart measurements and fertilizer $N$ application}

The LCC developed by International Rice Research institute in 1996 with strips of six shades of green colour showing increasing intensity of colour with increasing number from 1 to 6 was used in the study. Ten disease-free rice plants were randomly selected from each plot. The topmost fully expanded leaf was placed on the top of leaf colour chart and colour of the middle part of the leaf was graded according to the corresponding colour strip on the LCC. During measurement, the leaf being measured was kept under the shade of the body to avoid the colour variance caused by sun light. In rice, a basal dose of $30 \mathrm{~kg} \mathrm{~N} / \mathrm{ha}$ was applied 0 to 7 DAS/DAT and LCC readings were taken at weekly intervals starting from 15 DAS/DAT of rice until initiation of flowering stage. When colour of 6 out of 10 leaves fell below a threshold of shade 4 on the LCC, $30 \mathrm{~kg} \mathrm{~N} / \mathrm{ha}$ was top dressed on the same day.

\section{Chemical analysis of soil samples}

Soil samples were taken from each plot at a depth of $20 \mathrm{~cm}$ and were dried at room temperature in shade and were sieved in $1 \mathrm{~mm}$ sieve. These soil samples were analyzed for available $\mathrm{N}, \mathrm{P}$ and $\mathrm{K}$ by using following procedure:

\section{Available nitrogen}

Available nitrogen was estimated by alkaline $\mathrm{KMnO}_{4}$ method where the organic matter in soil is oxidized with hot alkaline $\mathrm{KMnO}_{4}$ solution. The ammonia evolved during oxidation is distilled and trapped in boric acid mixed indicator solution. The amount of $\mathrm{NH}_{3}$ trapped was estimated by titrating with standard acid (Subbaiah and Asija, 1956) ${ }^{[54]}$

\section{Available phosphorus}

Available phosphorus was extracted with sodium bicarbonate $(0.5 \mathrm{M})$ at $\mathrm{pH} 8.5$ (Olsen's reagent) and the amount of $\mathrm{P}$ in the extract was estimated by chlorostannous reduced phosphormolybdate blue colour method using spectrophotometer at wave length of $660 \mathrm{~nm}$ (Jackson, 1973) ${ }^{[21]}$.

\section{Available potassium}

Available potassium was extracted with neutral normal ammonium acetate and determined using flame photometer (Jackson, 1973) ${ }^{[21] .}$ 
Chemical analysis of plant samples

Plant samples used for the study component were used for chemical study. Samples were dried in a drier for 48-72 hours at $65 \pm 5^{\circ} \mathrm{C}$ and dried plant samples were then grounded and sieved in $1 \mathrm{~mm}$ sieve. These grain and straw samples were analyzed for N, P and K by using following procedure.

\section{Methods and instruments used for estimation of major contents in plant materials}

\begin{tabular}{|c|l|}
\hline Element & \multicolumn{1}{|c|}{ Method/ instrument used and unit of content } \\
\hline Nitrogen\% & $\begin{array}{l}\text { The modified micro-Kjeldahl method (Jackson, 1973) }{ }^{[21]} \text { was used for the N\% in straw and grain by digesting samples in } \\
\text { sulphuric in a micro-Kjeldhal flask (digestion tube) on a hot plate. The distillation process was carried out using Nitrogen Analyser } \\
\text { Gerhart) and titration was carried out using digital burette. }\end{array}$ \\
\hline Phosphorus\% & $\begin{array}{l}\text { Vanadomolybdo phosphoric acid yellow colour method (Jackson, 1973) }{ }^{[21]} \text { was used and the intensity of yellow colour was read } \\
\text { with Spectro-photometer at 420 nm and the contents were expressed in terms of percentage phosphorus }\end{array}$ \\
\hline Potassium\% & $\begin{array}{l}\text { Flame emission photometery method (Jackson, 1973) }{ }^{[21]} \text { was used to estimate potassium content in di-acid digested samples and } \\
\text { reported as percent potassium. }\end{array}$ \\
\hline
\end{tabular}

\section{Nutrient uptake}

The nutrient uptake by rice at harvest was worked out by multiplying the values of their concentration with the yields using the following equation: Nutrient uptake by grain $=\frac{\text { Nutrient content } \times \text { grain yield }(\mathrm{kg} / \mathrm{ha})}{100}$ Nutrient uptake by straw $=\frac{\text { Nutrient content } \times \text { dry matter production }(\mathrm{kg} / \mathrm{ha})}{100}$

\section{Observation and sampling procedures \\ Results and Discussion \\ Nitrogen content and uptake}

Data pertaining to nitrogen content and uptake are presented in Table 1. Nitrogen uptake by grain, straw and total uptake by plants was significantly higher under transplanting method compared to other establishment methods. Under aerobic method nitrogen content in grain and total uptake were significantly less than other methods. While in case of straw, wet-direct seeded and aerobic methods caused similar nitrogen uptake.

Table 1: Nitrogen content $(\%)$ and uptake $(\mathrm{kg} / \mathrm{ha})$ in grain and straw as influenced by the treatments.

\begin{tabular}{|c|c|c|c|c|c|}
\hline \multirow{2}{*}{ Treatments } & \multicolumn{2}{|c|}{ N content (\%) } & \multicolumn{2}{c|}{ N uptake (kg/ha) } & \multirow{2}{*}{ Total uptake (kg/ha) } \\
\cline { 2 - 5 } & Grain & Straw & Grain & Straw & \\
\hline Establishment methods & & & & & 104 \\
\hline Wet direct seeded & 1.23 & 0.568 & 69.5 & 34.4 & 100 \\
\hline Aerobic & 1.21 & 0.545 & 66.6 & 33.6 & 111 \\
\hline Transplanted & 1.25 & 0.574 & 74.9 & 36.1 & 0.4 \\
\hline S.E.m \pm & 0.004 & 0.004 & 0.4 & 0.3 & 2 \\
\hline C.D. (5\%) & 0.01 & 0.017 & 1.7 & 1.2 & \\
\hline Nutrient management & & & & & 93 \\
\hline RDF & 1.19 & 0.528 & 62.6 & 29.8 & 103 \\
\hline 75\% RDF+FYM(equiv. to 25\%N) & 1.23 & 0.578 & 68.4 & 34.9 & 105 \\
\hline 150\%RDF & 1.21 & 0.546 & 70.7 & 34.4 & 109 \\
\hline RDF(LCC based N) & 1.24 & 0.563 & 73.5 & 35.7 & 116 \\
\hline RDF+5tFYM/ha & 1.26 & 0.597 & 76.8 & 38.6 & 1.6 \\
\hline S.E.m \pm & 0.004 & 0.005 & 1.04 & .83 & 5 \\
\hline C.D. (5\%) & 0.01 & 0.015 & 3.0 & 2.4 & \\
\hline
\end{tabular}

Among nutrient management treatments, $\mathrm{RDF}+5 \mathrm{tFYM} / \mathrm{ha}$ caused significantly higher and RDF alone registered significantly lower $\mathrm{N}$ uptake by grain, straw and also the total uptake. $\mathrm{N}$ uptake by grain and total uptake was similar due to $75 \% \mathrm{RDF}+\mathrm{FYM}$ (equivalent to $25 \% \mathrm{~N}$ ) and $150 \% \mathrm{RDF}$ but significantly less than RDF (LCC based $\mathrm{N}$ ) and $\mathrm{RDF}+5 \mathrm{tFYM} / \mathrm{ha}$. The straw $\mathrm{N}$ content was similar due to
$75 \% \mathrm{RDF}+\mathrm{FYM}$ (equivalent to $25 \% \mathrm{~N}$ ), $150 \% \mathrm{RDF}$ and $\mathrm{RDF}$ (LCC based N).

\section{Phosphorus content and uptake}

Data pertaining to phosphorus content and uptake are presented in Table 2.

Table 2: Phosphorus content $(\%)$ and uptake $(\mathrm{kg} / \mathrm{ha})$ in straw and grain as influenced by the treatments

\begin{tabular}{|c|c|c|c|c|c|}
\hline \multirow{2}{*}{ Treatments } & \multicolumn{2}{|c|}{ P content (\%) } & \multicolumn{2}{c|}{ P uptake (kg/ha) } & \multirow{2}{*}{ Total uptake (kg/ha) } \\
\cline { 2 - 5 } & Grain & Straw & Grain & Straw & \\
\hline Establishment methods & & & & & \\
\hline Wet direct seeded & 0.368 & 0.111 & 20.7 & 6.7 & 28 \\
\hline Aerobic & 0.349 & 0.106 & 19.2 & 6.5 & 26 \\
\hline Transplanted & 0.383 & 0.117 & 23.0 & 7.4 & 30 \\
\hline S.E.m \pm & 0.002 & 0.006 & 0.3 & 0.07 & 0.4 \\
\hline C.D. (5\%) & 0.010 & 0.002 & 1.2 & 0.3 & 1 \\
\hline Nutrient management & & & & & 24 \\
\hline RDF & 0.350 & 0.101 & 18.3 & 5.7 & 27 \\
\hline $75 \%$ RDF+FYM(equiv. to 25\% N) & 0.366 & 0.115 & 20.2 & 6.9 & 28 \\
\hline 150\%RDF & 0.355 & 0.108 & 20.6 & 6.8 & \\
\hline
\end{tabular}




\begin{tabular}{|c|c|c|c|c|c|}
\hline RDF $($ LCC based N) & 0.362 & 0.114 & 21.4 & 7.2 & 29 \\
\hline RDF+5tFYM/ha & 0.400 & 0.120 & 24.3 & 7.8 & 32 \\
\hline S.E.m \pm & 0.004 & 0.0014 & 0.46 & 0.17 & 0.6 \\
\hline C.D. $(5 \%)$ & 0.011 & 0.004 & 1.4 & 0.5 & 2 \\
\hline
\end{tabular}

Phosphorus content and uptake by crop was significantly higher due to transplanting method compared to other methods. Aerobic method registered significantly less phosphorus content and uptake in grain, straw as well as total phosphorus uptake except for phosphorus uptake by straw, where wet-direct seeded and aerobic methods resulted in comparable phosphorus uptake.

Among nutrient management treatments, $\mathrm{RDF}+5 \mathrm{tFYM} / \mathrm{ha}$ caused significantly higher and RDF alone caused significantly lower phosphorus content and uptake by rice crop compared to remaining nutrient management treatments. The use of $75 \%$ RDF+FYM (equivalent to $25 \% \mathrm{~N}$ ), $150 \% \mathrm{RDF}$ and RDF (LCC based N) treatments caused similar phosphorus content and uptake by rice crop. However, $75 \%$ RDF+FYM (equivalent to $25 \% \mathrm{~N}$ ) and RDF (LCC based $\mathrm{N})$ treatments registered similar phosphorus content in straw but significantly higher than $150 \%$ RDF.

\section{Potassium content and uptake}

Data pertaining to potassium content and uptake are presented in Table 3. Potassium content and uptake in grain and total uptake by plant was significantly higher due to transplanting method compared to other establishment methods. However, aerobic method registered significantly less potassium content in straw compared to wet-direct seeded and transplanted rice which had comparable straw potassium content. The wetdirect seeded and aerobic methods resulted in similar potassium content by grain and potassium uptake by grain, straw and plant uptake.

Among nutrient management treatments potassium content and uptake by grain, straw and plant was significantly higher due to RDF+5t FYM/ha and significantly lower due to RDF compared to remaining treatments. Potassium content in grain due to $75 \% \mathrm{RDF}+\mathrm{FYM}$ (equivalent to $25 \% \mathrm{~N}$ ) and RDF (LCC based $\mathrm{N}$ ) was similar but significantly higher than RDF alone. The straw potassium content due to $150 \% \mathrm{RDF}$, being at par with RDF (LCC based N), was significantly less compared to $75 \% \mathrm{RDF}+\mathrm{FYM}$ (equivalent to $25 \% \mathrm{~N}$ ) treatment.

Significantly higher uptake of total nitrogen, phosphorus and potassium by the rice crop was noticed in transplanting method of cultivation compared to the aerobic and wet-direct seeded methods. Continuous flooding under transplanting method coupled with the application of FYM might have improved the soil physio-chemical properties and thus root activity to improve the uptake of nutrients (Awan et al., 1989 and Song et al., 2009) [3, 52]. Also, the higher uptake of nutrients by rice crop under transplanting method might have occurred due to minimum inter and intra-plant competition for resources which must have facilitated the increased uptake of nutrients by grain and straw (Saikia et al., 1992) ${ }^{[47]}$. However, apart from lesser competition for resources, the higher uptake of nutrients under transplanting method might also be due to higher grain and straw yield under transplanting method as the uptake is a function of yield and nutrient content. This finding is in accordance to those of Jaiswal and Singh (2001) [23].

Increased uptake of nutrients was also observed with the application of $\mathrm{RDF}+5 \mathrm{tFYM} / \mathrm{ha}$. The supply of timely required nutrients through $\mathrm{RDF}+5 \mathrm{tFYM} / \mathrm{ha}$ might have supplied balanced nutrition which resulted in enhanced nutrient uptake. Like-wise increased concentration of nutrients in grain and straw were also observed with the application of $\mathrm{RDF}+5 \mathrm{tFYM} / \mathrm{ha}$ compared to other nutrient management treatments (Jacqueline et al., 2008) ${ }^{[22]}$. The higher uptake of nutrient by plant due to $\mathrm{RDF}+5 \mathrm{tFYM} / \mathrm{ha}$ was also reported by Ghosh et al. (2014). Application of FYM in combination with inorganic fertilizers significantly increases $\mathrm{N}$ uptake by rice crop and also this combination proved helpful in increased uptake of phosphorus by rice crop over RDF alone (Zhang et al., 1998) ${ }^{[58]}$.

The increased uptake of $\mathrm{N}$ might have helped to extract more $\mathrm{K}$ from soil has been reported by Pal et al. (2005) ${ }^{[38]}$. Also, Bhadoria and Prokash (2003) ${ }^{[7]}$ observed significantly greater $\mathrm{K}$ uptake by the rice plants using organic manures in combination with chemical fertilizers over the application of $100 \%$ RDF or organic matter alone. These results are in the agreement with the findings of Sreelatha et al. (2006) ${ }^{[53]}$, who reported that, the application of organic manure and chemical fertilizers significantly increases $\mathrm{K}$ uptake by rice. The application of FYM in combination with fertilizers significantly increased the availability of nutrients. It might be due to the fact that FYM with inorganic fertilizers enhances the nutrient uptake by making linkages with a part of nutrient elements and prevented them from leaching and other losses (Greenland, 1971) ${ }^{[18]}$.

Table 3: Potassium content $(\%)$ and uptake $(\mathrm{kg} / \mathrm{ha})$ in straw and grain as influenced by the treatments

\begin{tabular}{|c|c|c|c|c|c|}
\hline \multirow{2}{*}{ Treatments } & \multicolumn{2}{|l|}{ Potassium content (\%) } & \multicolumn{2}{c|}{ Potassium uptake (kg/ha) } & \multirow{2}{*}{ Total uptake (kg/ha) } \\
\cline { 2 - 5 } & Grain & Straw & Grain & Straw & \\
\hline Establishment methods & & & & & \\
\hline Wet direct seeded & 0.461 & 1.51 & 26.04 & 91.8 & 118 \\
\hline Aerobic & 0.454 & 1.48 & 25.02 & 91.5 & 117 \\
\hline Transplanted & 0.479 & 1.53 & 28.69 & 96.5 & 125 \\
\hline S.E.m \pm & 0.001 & 0.001 & 0.27 & 0.94 & 1.1 \\
\hline C.D. (5\%) & 0.007 & 0.02 & 1.07 & 3.7 & 5 \\
\hline Nutrient management & & & & & 105 \\
\hline RDF & 0.441 & 1.44 & 23.07 & 81.7 & 119 \\
\hline 75\% RDF+FYM(equiv. to 25\% N) & 0.470 & 1.53 & 25.99 & 92.9 & 121 \\
\hline 150\%RDF & 0.456 & 1.49 & 26.52 & 94.2 & 124 \\
\hline RDF(LCC based N) & 0.466 & 1.51 & 27.55 & 96.3 & 131 \\
\hline RDF+5tFYM/ha & 0.491 & 1.56 & 29.79 & 101.2 & \\
\hline S.E.m \pm & 0.004 & 0.008 & 0.39 & 1.8 & \\
\hline C.D. (5\%) & 0.008 & 0.02 & 1.10 & 5.5 & \\
\hline
\end{tabular}


Increase in nitrogen, phosphorus and potassium uptake by rice crop was associated with corresponding increase in grain and straw yields (Table 8) in RDF+5tFYM/ha treatment.

\section{Available N, $P$ and $K$ in soil}

Data pertaining to available $\mathrm{N}, \mathrm{P}$ and $\mathrm{K}$ in soil are presented in Table 4. Available N, P and K in soil remained unaffected due to different methods of establishment, however higher values were obtained in transplanting method. Different nutrient management treatments significantly affected available $\mathrm{N}, \mathrm{P}$ and $\mathrm{K}$ in soil. The values of available $\mathrm{N}, \mathrm{P}$ and $\mathrm{K}$ in soil were significantly higher with application of $\mathrm{RDF}+5 \mathrm{tFYM} / \mathrm{ha}$ and significantly lower due to RDF alone compared to remaining treatments except in case of available $\mathrm{P}$ where RDF, being at par with $150 \% \mathrm{RDF}$, caused significant reduction in available $\mathrm{P}$ compared to remaining treatments. Available $\mathrm{N}$ in soil due to $75 \% \mathrm{RDF}+\mathrm{FYM}$ (equivalent to $25 \% \mathrm{~N}$ ) and RDF (LCC based $\mathrm{N}$ ) was similar but significantly higher than $150 \%$ RDF. Soil available $\mathrm{K}$ in soil due to $\mathrm{RDF}+5 \mathrm{tFYM} / \mathrm{ha}$ remained at par with $75 \%$ RDF+FYM (equivalent to $25 \% \mathrm{~N}$ ) but caused significantly more soil available $\mathrm{K}$ compared to other nutrient management treatments. Use of RDF and RDF (LCC based $\mathrm{N}$ ) caused similar soil available $\mathrm{K}$ but significantly less than $75 \% \mathrm{RDF}+\mathrm{FYM}$ (equivalent to $25 \% \mathrm{~N}$ ) and significantly higher than RDF.
In present study due to different establishment methods no significant result was observed on the availability of nitrogen, phosphorus and potassium in soil after the harvest of rice crop. It might be due to short term study conducted on rice under different establishment methods, which could not led to any influence on the availability of $\mathrm{N}, \mathrm{P}$ and $\mathrm{K}$. However, $\mathrm{RDF}+5 \mathrm{tFYM} / \mathrm{ha}$ treatment recorded significantly higher status of available $\mathrm{N}, \mathrm{P}$ and $\mathrm{K}$ in soil compared to $\mathrm{RDF}$ alone. This might be due to better integration of inorganic and organic fertilizer sources which has led to increased availability of nutrients in soil. As the rate of decomposition of farmyard manure is comparatively slow in contrast to the inorganic fertilizers alone and due to slow decomposition and gradual release of the nutrients into the labile pool and become available for longer duration (Das et al., 2014) ${ }^{[10]}$. Prasad (1994) ${ }^{[40]}$ also observed an increase in availability of nutrients in soil for longer duration with the application of FYM along with 100 per cent recommended dose of fertilizers. Application of FYM to rice increased soil fertility status due to an increase in soil available N, P and $\mathrm{K}$ contents (Meelu and Morris, 1984 and Kumar et al., 1992) [28]. Therefore, an integrated approach with the use of organic and inorganic inputs is essential as it nourishes the soil in many ways and supplies all the essential nutrients to crops in sufficient amounts and makes nutrients readily available in soil for longer duration (Kalyanasundaram and Kumar, 2003) [26].

Table 4: Available N, P and K in soil as influenced by various treatments.

\begin{tabular}{|c|c|c|c|}
\hline Treatments & Available N (kg/ha) & Available P (kg/ha) & Available K (kg/ha) \\
\hline Establishment methods & & & \\
\hline Wet direct seeded & 235 & 21 & 232 \\
\hline Aerobic & 234 & 21 & 230 \\
\hline Transplanted & 235 & 22 & 234 \\
\hline S.E.m \pm & 0.7 & 0.5 & 0.8 \\
\hline C.D. (5\%) & Ns & Ns & Ns \\
\hline Nutrient management & & & 224 \\
\hline RDF & 222 & 19 & 237 \\
\hline 75\% RDF+FYM(equiv. to 25\% N) & 237 & 22 & 229 \\
\hline 150\%RDF & 231 & 20 & 232 \\
\hline RDF(LCC based N) & 235 & 21 & 239 \\
\hline RDF+5tFYM/ha & 242 & 24 & 3 \\
\hline S.E.m \pm & 0.9 & 0.4 & \\
\hline C.D. $(5 \%)$ & 3 & 1 & \\
\hline
\end{tabular}

\section{Conclusion}

Based on above studies, it is concluded that under normal condition, transplanting method along with application of $\mathrm{RDF}+5 \mathrm{tFYM} / \mathrm{ha}$ and RDF (LCC based N) can be recommended for better soil characteristics.

\section{References}

1. Alam MM, Ladha JK, Rahaman KS, Foyjunnessa HR, Khan AH, Buresh RJ. Leaf color chart for managing Nitrogen fertilizer in lowland rice (Oryza sativa L.) in Bangladesh. Agronomy Journal. 2005; 97(3):949-959.

2. Aslam M, Hussain S, Ramzan M, Akhter M. Effect of different establishment techniques on rice yields and its attributes. J Anim. Pl. Sci. 2008; 18(2-3).

3. Awan IU, Alizai HU, Chaudhary FM. Comparative study of direct seeding and transplanting methods on rice yield. Sar. J Agri. 1989; 5:119-124.

4. Azad BS, Leharia SK. Yield of rice through integrated nutrient management under irrigated conditions. Annals Agril. Res. 2001; 22:471-475.
5. Baker R, Herdt RW, Rose B. The rice economy in Asia. Resource for the future, Washington, D.C, 1985.

6. Balamurali P. Influence of organic farming and integrated nutrient management practices on short grain scented rice, M.Sc. (Agri.) Thesis, Tamil Nadu Agric. Univ., Coimbatore (TN), 2006.

7. Bhadoria PBS, Prokash YS. Relative influence of organic manures in combination with chemical fertilizer in improving rice productivity of lateritic soil, Journal of Sustainable Agriculture. 2003; 23(1):77-87.

8. Bouman BAM, Xiaoguang Y, Huaqui W, Zhiming W, Junfang Z, Changgui W et al. Aerobic rice: A new way growing rice (Oryza sativa L.) in water short areas. (In:) Proceedings of the 12th International Soil Conservation Organization Conference, Tsinghua University, Beijing, China, 2002, 175-181.

9. Dahipale AV, Giri DG, Thakre GV, Giri MD. Effect of integrated nutrient management on yield and yield contributing parameters of scented rice. Annals of Plant Physiology. 2003; 17(1):24-26. 
10. Das A, Patel DP, Munda GC, Ramkrushna GI, Kumar M, Ngachan SV. Improving productivity, water and energy use efficiency in lowland rice (Oryza sativa L.) through appropriate establishment methods and nutrient management practices in the mid altitudes of north east India. Experimental Agriculture. 2014; 50(3):353-375.

11. Ebaid RA, El-Refaee IS. Utilization of rice husk as an organic fertilizer to improve productivity and water use efficiency in rice fields. African Crop Science Conference Proceedings. 2007; 8:1923-1928.

12. Economic Survey of India. Agriculture statistics at glance, 2014, 35.

13. Ehsanullah Iqbal I, Ahmad A, Randhawa SA. Effect of direct seeding and transplanting methods on the yield and quality of fine rice basmati-370. International Journal of Agriculture and Bio. 2000, 251-252.

14. Farooq M, Kadambot H, Siddique M, Rehman H, Aziz T. Rice direct seeding; Fxperiences, challenges and opportunities. Soil Till. Res. 2011; 111:87-98.

15. Food and Agriculture Organization (F.A.O). China: Recycling of organic waste in agriculture. Report on a FAO/UNDP study tour to the People's Republic of China, April-May, FAO. Soil Bull. Rome, 1977.

16. Gaur AC, Neelakantan S, Dargan KS. Organic manures. I.C.A.R. Tech. Bull. (Agric.) 1990, 25.

17. Gitsopanlos TK, Willams F. Effects of Oxadiargyl on direct seeded rice under aerobic and anaerobic conditions. Weed Res. 2004; 44:329-334.

18. Greenland DI. Changes in nitrogen status and fertility of soil. Soil and Fertilizer Abst. 1971; 34:268-272.

19. Gupta RK, Naresh RK, Hobbs PR, Ladha JK. Adopting conservation agriculture in rice-wheat systems of the Indo-Gangetic Plains-New opportunities for saving on water. In "Proceedings of the International Workshop on Water-Wise Rice Production" (Bouman BAM, Hengsdijk H, Hardy B, Bindraban B, Toung TP, Ladha JK (eds.) International Rice Research Institute, Los Banos, Philippines, 2002, 207-22.

20. Ishizuka Y. Physiology of rice plant. Advances in Agronomy. 1971; 23:241-315.

21. Jackson ML. Soil chemical analysis, Prentice Hall of India private limited, New Delhi, 1973, 186-192, 195196.

22. Jacqueline A, Prudente A, Gilbert C, Sigua M, Manoch $\mathrm{K}$, Alfredo D. Improving yield and nutrient uptake potentials of Japonica and Indica rice varieties with nitrogen fertilization. Journal of Agricultural Science. 2008; 4(4):427-434

23. Jaiswal VP, Singh GR. Effect of planting methods, source and level of nitrogen on the growth and yield of rice (Oryza sativa L.) and on succeeding wheat (Triticum aestivum). Indian Journal of Agron. 2001; 46(1):5-11.

24. Jayabal A, Palaniappan SP, Chellaiah S. Evaluation of integrated nutrient management technique in rice. Oryza, 1999; 36(3):263-265.

25. Kanungo AP, Roul PK. Response of transplanted summer rice (Oryza sativa L.) genotypes to varying levels of fertility and plant density. Indian Journal Agron. 1994; 39(2):216-219.

26. Kalyanasundaram D, Kumar S. Integrated nutrient management in hybrid rice ADTRH-1. Advances in plant Science. 2003; 16(1):171-175.

27. Kumar J. Integrated use of organic and inorganic nutrient sources in transplanted rice. M.Sc. (Agric.) Thesis,
Govind Ballabh Pant University of Agriculture and Technology, Pantnagar, Uttarakhand, 2001.

28. Kumar K, Meelu OP, Singh Y, Singh B. Effect of continuous application of organic manure on the physical properties of soil in a rice-wheat cropping system. Int. Rice Res. Newsletter. 1992; 17:16-17.

29. Luzes EF. Study of soil levelling and sowing method in rice crop in Purtgal, Lavoura Arrozeina. 1991; 44:21-23.

30. Mellu OP, Morris RA. Integrated management of plant nutrient in rice and rice based cropping systems. Fertilizer News. 1984; 29:65-69.

31. Miller HB. Poultry litter induces tillering in rice. $\mathbf{J}$ Sustain. Agric. 2007; 31:1-12.

32. Mirza H, Ahamed KU, Rahmatullah NM, Akhter KN, Rahman ML. Plant growth characters and productivity of wetland rice (Oryza sativa L.) as affected by application of different manures. Emir. J Food Agric. 2010; 22(1):4658.

33. Muhammad I. Response of wheat growth and yield to various levels of compost and organic manure. Pak. J Bot. 2008; 40(5):2135-2141.

34. Murali MK, Setty RA. Effect of fertilizer, vermicompost and tricontanol on growth and yield of scented rice. Oryza, 2004; 41(1-2):57-59.

35. Nambiar KKM, Abrol IP. Long term fertilizer experiments in India-An overview. Fert. News. 1989; 34(4): 11-20.

36. Nedunchezhiyan M, Laxminarayan K. Site Specific Nutrient Management for Rice (Oryza sativa L.). Orissa Review, 2011, 62-64.

37. Olsen SR, Cole CV, Wtanable FS, Dean LA. Estimation of available phosphorus in soils by extraction with sodium bicarbonate, U.S. Deptt. Agri. Circular No. 1954; 939:19.

38. Pal SK, Chowdury A, Gunri SKK. Effect of integrated nitrogen management and plant density on yield and nitrogen balance of rice under lowland situation. Oryza. 2005; 42(1):41-47.

39. Pandey N, Verma VK, Tripathi RS. Effect of FYM combination with nutrient doses on rice (Oryza sativa L.) yield. Indian Journal of Agronomy. 2007; 52:335-338.

40. Prasad B. Integrated nutrient management for sustainable agriculture, Agric. Fert. News. 1994; 39(9):19-25.

41. Rajput AM, Shroff VN, Despande SL. Impact of mixed organic farming on soybean and potato. Crop Res. 1995; 10(3):258-260.

42. Rakshit A, Sarkar NC, Debashish S. Influence of organic manures on productivity of two varieties of rice. J Cent. Eur. Agric. 2008; 9(4):629-634.

43. Ramamoorthy K, Thiyagarajan TM, Subbaiah SV. Integerated nitrogen management through grain legumes and green manures in irrigated tropical rice based cropping systems-A review Agric. Review. 2000; 22(3/4):141-162.

44. Ravi S, Ramesh S, Chandrasekaran B. Exploitation of hybrid vigour in rice (Oryza sativa L.) through green manure and leaf colour chart (LCC) based N application. Agronomy Journal. 2007; 99(3):929-932.

45. Reddy GE, Suresh BG, Sravan T. Correlation and path analysis for yield and yield attributes in rice (Oryza sativa L.) genotypes. Int. Journal of Plant Sciences. 2013; 8(2):391-394.

46. Salem AKM. Effect of nitrogen levels, plant spacing and time of farmyard manure application on the productivity 
of rice. Journal of applied sciences research. 2006; 2(11):980-987.

47. Saikia L, Bhattacharyya HC, Pathak AK. Seedling and transplanting practice of rice with and without $\mathrm{N}, \mathrm{P}$ and K. Indian Journal Agron. 1992; 37(1):155-157.

48. Sarker MAR, Pramanik MYA, Faruk GM, Ali MY. Effect of green manures and levels of nitrogen on some growth attributes of transplant aman rice. Pakistan J Biol. Sci. 2004; 7:739-742.

49. Sharma AR, Mitra BN. Direct and residual effect of organic material and phosphorus fertilizers in rice (Oryza sativa L.) based cropping system. Indian J Agron. 1994; 36: 299-303.

50. Singh A, Singh RD, Awasthi RP. Organic and inorganic sources of fertilizers for sustained productivity in rice (Oryza sativa L.)-wheat (Triticum aestivum), 1996.

51. Singh AK, Choudhary BU, Bouman BAM. Effects of rice (Oryza sativa L.) establishment methods on crop performance, water use, and mineral nitrogen. (In:) Proceedings of a Thematic Workshop on Water- Wise Rice Production, held at IRRI. International Rice Research Institute, Los Banos, Philippines, 2003, 223235.

52. Song C, Shenguan C, Xin C. Genotypic differences in growth and physiological responses to transplanting and direct seeding cultivation in rice. Rice Sci. 2009; 16:143150.

53. Sreelatha T, Raju AS, Raju AP. Effect of different doses of farm yard manure and poultry manure and their interaction with fertilizer nitrogen on yield and nutrient uptake in mesta-rice cropping system. Journal of Crop Research. 2006; 34:41-47.

54. Subbaiah BV, Asija GL. A rapid producer for the determination of available nitrogen in soil. Current Sci. 1956; 25:259-262.

55. Subramanian V. Substitution of inorganic $N$ with organic manure in lowland rice. M.Sc. (Agric.) Thesis, AC and RI, Madurai, 1997.

56. Sudhir Y, Gill MS, Kukal SS. Performance of direct seeded basmati rice in loamy sand in semi-arid subtropical India. Soil Till. Res. 2007; 97:229-238.

57. Tuong TP, Bouman BAM. Rice production in water scare environments. (In:) Water Productivity in Agriculture: Limits and Opportunities for Improvement. CABI Publishing, Wallingford, UK, 2003, 53-67.

58. Zhang YL, Shen QR, Cao CY. Effects of organic manure on soil organic phosphorus functions and their bioavailability. Journal of Nanjing Agricultural University. 1998; 21(3):59-63.

59. Zheng J, Lu XJ, Jiang XL, Tang YL. The system of rice intensification (SRI) for super-high yields of rice in Sichuan Basin. (In:) New Directions for a Diverse Planet: Proceedings for the 4th International Crop Science Congress, 26 September - 1 October, Brisbane, Australia, 2004. 